Research Article

\title{
A Simple Matrix Approach to Determination of the Helium Atom Energies
}

\author{
Redi Kristian Pingak ${ }^{1, a}$, Rosara Kolmate ${ }^{1, b}$, and Bernandus ${ }^{1, c}$ \\ ${ }^{1}$ Department of Physics, Faculty of Science and Engineering, Universitas Nusa Cendana \\ Jalan Adisucipto Penfui, Kupang 85001, Indonesia
}

e-mail: ${ }^{\mathrm{a}}$ rpingak@staf.undana.ac.id, ${ }^{\mathrm{b}}$ rosakolmate18@gmail.com, and ${ }^{\mathrm{c}}$ bernandus@staf.undana.ac.id

\begin{abstract}
Calculation of He atomic energy levels using the first order perturbation theory taught in the Basic Quantum Mechanics course has led to relatively large errors. To improve its accuracy, several methods have been developed but most of them are too complicated to be understood by undergraduate students. The purposes of this study are to apply a simple matrix method in calculating some of the lowest energy levels of He atom ( $1 s^{2}$, triplet $1 s 2 s$, and singlet $1 s 2 s$ states) and to reduce errors obtained from calculations using the standard perturbation theory. The convergence of solutions as a function of the number of bases is also examined. The calculation is done analytically for 3 bases and computationally with the number of bases $3 \leq n \leq 25$ using MATHEMATICA. First, the 2-electron wave function of the Helium atom is written as the multiplication of two $\mathrm{He}^{+}$ion wave functions, which are then expanded into finite dimension bases. These bases are used to calculate the elements of the Hamiltonian matrix, which are then substituted back to the energy eigenvalue equation to determine the energy values of the system. Based on the calculation results, the error obtained for the He ground state energy using 3 bases is $2.51 \%$, smaller than the errors of the standard perturbation theory (5.28\%). Despite the fact that the error is still relatively large from the analytical calculations for singlet-triplet $1 s 2 \mathrm{~s}$ energy splitting of He atom, this error is successfully reduced significantly as more bases were used in the numerical calculations. In particular, for $n=25$, the current calculation error for all states is much smaller than the errors obtained from calculations using standard perturbation theory. In conclusion, the analytical calculations for the energy eigenvalue equation for the 3 lowest states of the Helium atom using 3 bases have been carried out. It was also found in this study that increasing the number of bases in our numerical calculations has significantly reduced the errors obtained from the analytical calculations.
\end{abstract}

Keywords: Helium atom, matrix approach, ground state energy, 1 s 2 s singlet-triplet energy

\section{Pendekatan Matriks Sederhana untuk Penentuan Tingkat-Tingkat Energi Atom Helium}

\begin{abstract}
Abstrak
Perhitungan tingkat energi atom He menggunakan teori perturbasi orde 1 yang diajarkan di mata kuliah mekanika kuantum dasar menghasilkan eror yang cukup besar. Untuk meningkatkan akurasinya, telah banyak metode yang dikembangkan namun kebanyakan dari metode ini menggunakan metode-metode tingkat lanjut yang terlalu rumit dipahami oleh mahasiswa strata 1. Tujuan penelitian ini adalah untuk menerapkan suatu metode matriks sederhana dalam menghitung beberapa tingkat energi terendah atom
\end{abstract}

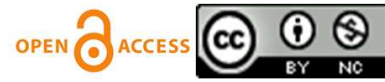


Jurnal Penelitian Fisika dan Aplikasinya (JPFA), 2019; 9(1): 10-21

He (state $1 s^{2}, 1 s 2 s$ triplet, dan $1 s 2 s$ singlet) dan untuk mengurangi eror yang diperoleh dari perhitungan menggunakan teori perturbasi standar. Konvergensi solusi sebagai fungsi jumlah basis juga dikaji. Perhitungan dilakukan secara analitik untuk 3 basis dan secara komputasi dengan jumlah basis $3 \leq n \leq 25$ menggunakan MATHEMATICA. Pertama, fungsi gelombang 2 elektron atom Helium ditulis sebagai perkalian 2 buah fungsi gelombang ion $\mathrm{He}^{+}$, yang kemudian diekspansi menjadi basis-basis berdimensi berhingga. Basis-basis ini digunakan untuk menghitung elemen-elemen matrix Hamiltonian, yang selanjutnya disubstitusi kembali ke persamaan nilai eigen energi untuk menentukan nilai-nilai energi sistem. Berdasarkan hasil perhitungan, eror yang diperoleh untuk energi keadaan dasar He dengan menggunakan 3 basis adalah 2,51\%, jauh lebih kecil dibanding eror dari teori perturbasi standar $(5,28 \%)$. Walaupun eror yang cukup besar masih diperoleh dari hasil perhitungan analitik kami untuk splitting energi singlet-triplet $1 s 2 s$ atom He, nilai eror ini berhasil dikurangi secara signifikan ketika semakin banyak basis digunakan dalam perhitungan numerik kami. Khususnya, untuk $n=25$, eror perhitungan kami untuk semua state jauh lebih kecil dari eror yang diperoleh dari perhitungan menggunakan teori perturbasi standar. Sebagai kesimpulan, perhitungan analitik untuk persamaan nilai eigen energi untuk 3 state terendah atom Helium menggunakan 3 basis telah dilakukan. Dalam penelitian ini juga ditemukan bahwa penambahan jumlah basis dalam perhitungan numerik kami telah berhasil mengurangi secara signifikan eror yang diperoleh dari perhitungan analitik.

Kata Kunci: atom Helium, pendekatan matriks, energi keadaan dasar, energi singlet-triplet $1 \mathrm{~s} 2 \mathrm{~s}$

PACS: 01.40.Fk, 02.10.Yn, 03.65.Ta, 31.15.B-

(C) 2019 Jurnal Penelitian Fisika dan Aplikasinya (JPFA).This work is licensed under CC BY-NC 4.0

\begin{aligned} \hline Article History: Received: May 16, 2018 & Approved with minor revision: May 16, 2019 \\ Accepted: June 26, 2019 & Published: June 30, 2019\end{aligned}

How to Cite: Pingak RK, Kolmate R, and Bernandus. A Simple Matrix Approach to Determination of the Helium Atom Energies. Jurnal Penelitian Fisika dan Aplikasinya (JPFA). 2019; 9(1): 10-21. DOI: https://doi.org/10.26740/jpfa.v9n1.p10-21.

\section{INTRODUCTION}

As part of the Quantum Mechanics courses in undergraduate programs, students are often asked to calculate energies of the $\mathrm{He}$ atom using standard first order timeindependent perturbation theory. This is a good exercise for the students as they are able to learn and apply quantum theory to solving real quantum problems. However, errors in the He atomic energies calculation obtained from the standard textbook perturbation theory calculations are relatively large, as it is estimated around $5.28 \%$ for ground state $1 \mathrm{~s}^{2}$ energy and about 201.44 \% for energy splitting of 1s2s singlet-triplet state. This often makes many undergraduates think that to obtain much better results than the first order perturbation theory for the He energies, one needs to apply more advanced methods which are inaccessible to them.

Many simple approaches have been developed to reduce errors obtained from standard perturbation theory calculations on the He atom. One study utilized the shooting method to calculate the singlet and triplet energy levels of the He atom [1]. The method used is familiar to undergraduate students since similar methods were used in treating the hydrogen atom in undergraduate Quantum Mechanics classes. Despite the simplicity of the method, their calculations on He energies agree well with the corresponding experimental values, with errors being $1.44 \%$ for ground state energy, $0.05 \%$ for $1 \mathrm{~s} 2 \mathrm{~s}$ triplet, and $0.33 \%$ for $1 \mathrm{~s} 2 \mathrm{~s}$ singlet energy. In addition, detailed density functional theory (DFT) 
calculations of ground state energy of the $\mathrm{He}$ atom was presented [2]. This method is believed to be accessible to undergraduates and give accurate results, with the error for the He ground state energy is estimated to be $1.44 \%$. Many other quantum calculations on the $\mathrm{He}$ atom have also been conducted recently using Hartree-Fock theory [3-4], variational methods [5-8], perturbative and variational methods [9], combination of Heisenberg's uncertainty principle and variational methods [10], Lagrange-mesh method [11], Hamilton-Jacobi equation [12], Bohr's theory-based methods [13-14], and analytic matrix calculation with logarithmic terms [15].

In addition, many high quality quantum calculations have now been performed massively and effectively due to the increasing computing capacity [16]. This allows the use of various computer-based method to perform more accurate calculations of energies of the $\mathrm{He}$ atom. Some of the methods are variational quantum Monte Carlo method [17-20], path integral Monte Carlo method [21], finite element method [22], finite volume discretization method [23], variational approach with free iterative complement - interaction method [24], Hylleraas - Configuration interaction [25], fifth-order variational perturbation theory [26], extensive variational calculations [27], and numeric matrix method [28-30].

Most of the above mentioned methods are very accurate to calculate the energy, but they are considered too advanced for undergraduates. In 2015, Masse and Walker [31] developed a simple method using matrix mechanics introduced in Quantum Mechanics course for undergraduate program to numerically calculate energy of $1 \mathrm{~s}^{2}, 1 \mathrm{~s} 2 \mathrm{~s}$ triplet, and $1 \mathrm{~s} 2 \mathrm{~s}$ singlet states using MATHEMATICA. With seven basis states, errors obtained from their calculations were $2.14 \%, 0.19 \%$, and $0.43 \%$ for the respective states. In addition, error for singlet-triplet energy splitting was about $17 \%$, much lower than the error obtained from standard $1^{\text {st }}$ order perturbation theory calculations (about $201.44 \%$ ).

However, in their article, Masse and Walker [31] did not provide an analytic calculation on the helium atom energies. Also, they only used 7 basis states in the expansion of the wave function. In this article, on the other hand, the analytic calculation on the helium atom energies is provided to highlight its simplicity as well as numeric calculation using various number of basis states to investigate the convergence of the solutions as a function of number of basis states.

The aim of this research is to apply a simple matrix approach to calculate energy eigenvalues of the low-lying states of the $\mathrm{He}$ atom $\left(1 \mathrm{~s}^{2}, 1 \mathrm{~s} 2 \mathrm{~s}\right.$ triplet, and $1 \mathrm{~s} 2 \mathrm{~s}$ singlet states), both analytically and computationally using various number of basis states. Convergence of the solutions as a function of number of basis states will also be studied. Through the implementation of the simple matrix approach to the calculation, it is expected to significantly increase the accuracy of standard $1^{\text {st }}$ order perturbation theory calculations on the energies of He atom. All calculations in this article are based on a matrix approach developed in [31]. It is expected that the approach presented in this study can be used as an alternative method along with other simple quantum calculation methods such as standard perturbation theory and variational approaches to perform simple but quite accurate calculations in Quantum Mechanics classes in undergraduate program.

In this article, the analytic calculation of the energies of the He atom is presented using $n=3$ basis states. After that, the convergence of the solutions is investigated as a function of number of basis states $(n)$. The basis states used in this article are formed using s orbitals. 


\section{METHOD}

Energies of the Helium atom are determined by solving the time independent of Schrödinger equation $\hat{H}|\Psi\rangle=E|\Psi\rangle$. In this article, the Schrödinger equation is solved by using a matrix approach, assuming that $|\Psi\rangle$ is expanded in finite number of basis states. In this approach, therefore, $|\Psi\rangle$ is an $(n \times 1)$

column vector and $\hat{H}$ is an $(n \times n)$ matrix, with $n$ being the number of basis states.

Overall, steps involved in the calculations of the $\mathrm{He}$ atom energies are as follows. First, Hamiltonian matrix is determined along with all its elements, using the usual equation $H_{p q}=\left\langle\psi_{p}|H| \psi_{q}\right\rangle$, where $H$ is the Hamiltonian of the $\mathrm{He}$ atom. To calculate the matrix elements, the wave function $\left|\psi_{P}\right\rangle$ has to be expanded first, depending on number of basis states one wants to use. Here, basis states used range from 3 to 25, therefore Hamiltonian is a matrix of $(n \times n)$ dimension where $3 \leq n \leq 25$. For $n=3$, both analytic and numeric calculations are presented while for $n \geq 4$ only numeric calculations are performed. Once all elements of the matrix are found, the matrix is then diagonalized. The diagonalization of this $n \times n$ matrix results in $n$ energy eigenvalues, the lowest three of which are the energy eigenvalues of $1 \mathrm{~s}^{2}, 1 \mathrm{~s} 2 \mathrm{~s}$ triplet, and $1 \mathrm{~s} 2 \mathrm{~s}$ singlet states. To simplify the calculations, Hartree atomic unit (a.u.) is used in this article.

\section{III.RESULTS AND DISCUSSION}

Elements of the $\mathrm{He}$ atom Hamiltonian Matrix

Hamiltonian operator can be represented in matrix form as follow

$H=\sum_{p, q} H_{p q}\left|\psi_{q}\right\rangle\left\langle\psi_{q}\right|$

Which can be represented as follows:

$$
H=\left[\begin{array}{cccc}
H_{11} & H_{12} & \ldots & H_{1 q} \\
H_{21} & H_{22} & \ldots & H_{2 q} \\
\ldots & \ldots & \ldots & \ldots \\
H_{p 1} & H_{p 2} & \ldots & H_{p q}
\end{array}\right]
$$

Where $H_{p q}$ are elements of the Hamiltonian matrix obtained as follows:

$H_{p q}=\left\langle\psi_{p}|H| \psi_{q}\right\rangle$

Here, $\left|\psi_{P}\right\rangle$ is the two-electron wave function, which can be written as a product of two $\mathrm{He}^{+}$ wave functions (orbital approximation). Using this approximation, $\left|\psi_{P}\right\rangle$ can be written

$\left|\psi_{P}\right\rangle=\left|\phi_{1} \phi_{2}\right\rangle=\left|n_{1} l_{1} n_{2} l_{2}\right\rangle$

As usual, the spatial wave function of hydrogenic wave function contains the radial function and the standard spherical harmonics. The normalized hydrogenic radial wave function (in a.u.) can be written in terms of Laguerre Polynomial

$R_{n l}(r)=\left\{\left(\frac{2 Z}{n}\right)^{3} \frac{(n-l-1) !}{(n+l) !(2 n)}\right\}^{\frac{1}{2}}\left(\frac{2 Z r}{n}\right)^{l} e^{-\frac{Z r}{n}} L_{n-l-1}^{2 l+1}\left(\frac{2 Z r}{n}\right)$

The radial function for $\mathrm{He}^{+}$ion $(Z=2)$ is therefore

$R_{n l}(r)=\left\{\frac{2(n-l-1) !}{n^{2}(n+l) !}\right\}^{\frac{1}{2}}\left(\frac{4}{n}\right)\left(\frac{4 r}{n}\right)^{l} e^{-\frac{2 r}{n}} L_{n-l-1}^{2 l+1}\left(\frac{4 r}{n}\right)$

Hamiltonian operator $H$ in equation (3) is nothing but the Hamiltonian of the $\mathrm{He}$ atom, 
consisting of the unperturbed Hamiltonian $H_{0}$ and the interaction potential $V$. Where,

$H_{0}=-\frac{\nabla_{1}^{2}}{2}-\frac{\nabla_{2}^{2}}{2}-\frac{2}{r_{1}}-\frac{2}{r_{2}}$

and

$V=\frac{1}{r_{12}}=\sum_{l m} \frac{4 \pi}{2 l+1} \frac{r_{<}^{l}}{r_{>}^{+1+}}(-1)^{m} Y_{l}^{-m}\left(\Omega_{1}\right) Y_{l}^{m}\left(\Omega_{2}\right)$

$V=\left\{\begin{array}{cl}\frac{1}{r_{1}}, & \text { if } r_{2}<r_{1} \\ \frac{1}{r_{2}}, & \text { if } r_{1}<r_{2}\end{array}\right.$

Therefore, equation (3) can be rewritten as

$$
H_{p q}=\left\langle\psi_{p}\left|H_{0}\right| \psi_{q}\right\rangle+\left\langle\psi_{p}|V| \psi_{q}\right\rangle
$$

Using orthornormality of the wave function, equation (9) becomes

$$
H_{p q}=E_{n_{1}, n_{2}}^{0} \delta_{p q}+\left\langle\psi_{p}|V| \psi_{q}\right\rangle
$$

Where $E_{n_{1}, n_{2}}^{0}$ is the unperturbed energy obtained by solving time-independent Schrödinger equation for hydrogenic ions, which is already solved in Quantum Mechanics classes in undergraduate program. As in the present case there are two electrons, $E_{n_{1}, n_{2}}^{0}$ is the superposition of the unperturbed energy of each electron, written as

$$
E_{n_{1}, n_{2}}^{0}=-\frac{2}{n_{1}^{2}}-\frac{2}{n_{2}^{2}}
$$

To evaluate equation (10), it can be written in its integral forms as

$$
\begin{aligned}
& H_{p q}=E_{n_{1}, n_{2}}^{0} \delta_{p q}+\left(Y_{0}^{0}\right)^{4} \iint R_{n_{1} 0}\left(r_{1}\right) R_{n_{2} 0}\left(r_{2}\right) \frac{1}{r_{12}} \\
& R_{n_{3} 0}\left(r_{1}\right) R_{n_{4} 0}\left(r_{2}\right) d^{3} r_{1} d^{3} r_{2}
\end{aligned}
$$

Where we have used that fact that only $\mathrm{s}$ orbitals are considered here, for which $l=0$. Since the angular integrals in the second term of equation (12) cancels $\left(Y_{0}^{0}\right)^{4}$, the 6-fold integrals in this equation reduce to 2 -fold integrals. Thus, equation (12) can be further simplified as follows

$$
\begin{aligned}
& H_{p q}=E_{n_{1}, n_{2}}^{0} \delta_{p q}+\iint r_{1}^{2} R_{n_{1} 0}\left(r_{1}\right) R_{n_{2} 0}\left(r_{2}\right) \frac{1}{r_{12}} \\
& r_{2}^{2} R_{n_{3} 0}\left(r_{1}\right) R_{n_{4} 0}\left(r_{2}\right) d r_{1} d r_{2}
\end{aligned}
$$

For convenience in calculations, equation (13) is written as

$$
\begin{aligned}
& H_{p q}=E_{n_{1}, n_{2}}^{0} \delta_{p q}+\iint P_{n_{1} 0}\left(r_{1}\right) P_{n_{2} 0}\left(r_{2}\right) \frac{1}{r_{12}} \\
& P_{n_{3} 0}\left(r_{1}\right) P_{n_{4} 0}\left(r_{2}\right) d r_{1} d r_{2}
\end{aligned}
$$

Where, our new radial function is now $P_{n l}(r)$, which is just the modified version of equation (6). Where

$$
P_{n l}(r)=\left\{\frac{2(n-l-1) !}{n^{2}(n+l) !}\right\}^{\frac{1}{2}}\left(\frac{4 r}{n}\right)^{l+1} e^{-\frac{2 r}{n}} L_{n-l-1}^{2 l+1}\left(\frac{4 r}{n}\right)
$$

As basis states used here consist of only $\mathrm{s}$ orbitals, then

$P_{n 0}(r)=\left\{\frac{2(n-1) !}{n^{2}(n) !}\right\}^{\frac{1}{2}}\left(\frac{4 r}{n}\right) e^{-\frac{2 r}{n}} L_{n-1}^{1}\left(\frac{4 r}{n}\right)$

Equations (8), (10), (11), (14), and (16) are the equations used to calculate elements of the Hamiltonian matrix for the $\mathrm{He}$ atom in this study.

\section{Analytic Solutions to Energy Eigenvalue Equation using 3 Basis States $(n=3)$}

Energy eigenvalue equation to be solved here is

$H|\Psi\rangle=E|\Psi\rangle$

Before solving equation (17) for $E$, Hamiltonian matrix elements $H_{\mathrm{PQ}}$ should be determined. In addition, since the wave function $|\Psi\rangle$ has infinite dimension, it has to be expanded in terms of Eigen states with finite dimension $|\Psi\rangle=\sum_{i=1}^{N} c_{i}\left|\psi_{i}\right\rangle$, where $N$ has 
to be finite. If its wave function is expanded in follows

3 basis states, then

$|\Psi\rangle=c_{1}\left|\psi_{1}\right\rangle+c_{2}\left|\psi_{2}\right\rangle+c_{3}\left|\psi_{3}\right\rangle$

In this section, the three bases used in performing the analytic calculation are as

$\left|\psi_{1}\right\rangle=|1 s 1 s\rangle ;\left|\psi_{2}\right\rangle=|1 s 2 s\rangle ;\left|\psi_{3}\right\rangle=|2 s 1 s\rangle$

From equation (10) and (19), the $3 \times 3$ Hamiltonian matrix for the $\mathrm{He}$ atom can be written

$$
H=\left[\begin{array}{ccc}
E_{1,1}^{0}+\langle 1 s 1 s|V| 1 s 1 s\rangle & \langle 1 s 1 s|V| 1 s 2 s\rangle & \langle 1 s 1 s|V| 2 s 1 s\rangle \\
\langle 1 s 2 s|V| 1 s 1 s\rangle & E_{1,2}^{0}+\langle 1 s 2 s|V| 1 s 2 s\rangle & \langle 1 s 2 s|V| 2 s 1 s\rangle \\
\langle 2 s 1 s|V| 1 s 1 s\rangle & \langle 2 s 1 s|V| 1 s 2 s\rangle & E_{2,1}^{0}+\langle 2 s 1 s|V| 2 s 1 s\rangle
\end{array}\right]
$$

Elements of the Hamiltonian matrix are determined as shown below. In this case, only the first element of the matrix is calculated, i.e. $H_{11}$. The rest of the elements are calculated exactly in the same way. For $H_{11}$, one has

$H_{11}=E_{1,1}^{0}+\langle 1 s 1 s|V| 1 s 1 s\rangle$

which can be rewritten in integral forms as the following equation

$H_{11}=E_{1,1}^{0}+\iint P_{10}\left(r_{1}\right) P_{10}\left(r_{2}\right) \frac{1}{r_{12}} P_{10}\left(r_{1}\right) P_{10}\left(r_{2}\right) d r_{1} d r_{2}$

Using equation (16) for $P_{10}(r)$, one obtains

$H_{11}=E_{1,1}^{0}+(32)^{2} \iint r_{1}^{2} e^{-4 r_{1}} \frac{1}{r_{12}} r_{2}^{2} e^{-4 r_{2}} d r_{1} d r_{2}$

To evaluate the integral in equation (23), $r_{1}$ is assumed to be constant so that integral over $r_{2}\left(I_{2}\right)$ is evaluated first.

$I_{2}=\int_{0}^{\infty} \frac{1}{r_{12}} r_{2}^{2} e^{-4 r_{2}} d r_{2}$

so that equation (23) can be rewritten

$H_{11}=E_{1,1}^{0}+(32)^{2} \int_{0}^{\infty} r_{1}^{2} e^{-4 r_{1}} d r_{1}\left(I_{2}\right)$

Then by using equation (8), $I_{x}$ can be evaluated as follows

$I_{2}=\frac{1}{r_{1}} \int_{0}^{r_{0}} r_{2}^{2} e^{-4 r_{2}} d r_{2}+\int_{r_{1}}^{\infty} r_{2} e^{-4 r_{2}} d r_{2}$ from which one obtains

$I_{2}=\frac{1}{32 r_{1}}\left\{\left(-2 r_{1}-1\right) e^{-4 r_{1}}+1\right\}$

Equation (27) is substituted back into equation (25) to give

$H_{11}=E_{1,1}^{0}+32 \int_{0}^{\infty}\left\{\left(-2 r_{1}^{2}-r_{1}\right) e^{-8 r_{1}}+r_{1} e^{-4 r_{1}}\right\} d r_{1}$

Integral in equation (28) is simply evaluated using partial integral to give

$\int_{0}^{\infty}\left\{\left(-2 r_{1}^{2}-r_{1}\right) e^{-8 r_{1}}+r_{1} e^{-4 r_{1}}\right\} d r_{1}=\frac{5}{128}$

Equation (28) then becomes

$H_{11}=E_{1,1}^{0}+32\left(\frac{5}{128}\right)$

Using equation (11) for $E_{1,1}^{0}$, the Hamiltonian matrix $H_{11}$ in equation (30) is finally found to be (in a.u.)

$H_{11}=-2.75$

All other Hamiltonian matrix elements $\left(H_{12}\right.$, $H_{13}, H_{21}, H_{22}, H_{23}, H_{31}, H_{32}$, and $H_{33}$ ) can be determined in the same way as $H_{11}$. All the results are summarized in the following $3 \times 3$ Hamiltonian matrix

$H=\left[\begin{array}{ccc}-2.7500 & 0.1787 & 0.1787 \\ 0.1787 & -2.0802 & 0.0439 \\ 0.1787 & 0.0439 & -2.0802\end{array}\right]$ 
Equation (32) is substituted to equation (17), and the characteristic equation for the energy eigenvalue equation is then solved to obtain three energy eigenvalues as follows.

$\operatorname{det}\left[\begin{array}{ccc}-2.7500-E & 0.1787 & 0.1787 \\ 0.1787 & -2.0802-E & 0.0439 \\ 0.1787 & 0.0439 & -2.0802-E\end{array}\right]=0$

From which one finally obtains (in a.u.)

$E_{1}=-2.8304$

$E_{2}=-2.1241$

$E_{3}=-1.9559$

where $E_{1}, E_{2}$, and $E_{3}$ correspond to energies of $1 \mathrm{~s}^{2}, 1 \mathrm{~s} 2 \mathrm{~s}$ triplet, and $1 \mathrm{~s} 2 \mathrm{~s}$ singlet states respectively. These values agree with the numeric calculations for $n=3$ (see Table 1).

Comparisons of relative errors in energies using our analytic calculations in equation (34) with standard textbook perturbation theory calculation are presented below, where all errors are calculated using experimental energies [32]. For He ground state energy $E_{1}$, relative error from calculations in this study is $2.51 \%$, significantly smaller than errors of the standard textbook perturbation theory calculation of $5.28 \%$ [33]. This indicates that with this simple analytic calculation using only 3 basis states, this study has proven significantly improvement in terms of accuracy than the standard textbook perturbation theory. It is believed in order to improve the current results, more basis states need to be included in the calculations. For the $\mathrm{He} 1 \mathrm{~s} 2 \mathrm{~s}$ excited state energies, on the other hand, errors resulted from the calculations are relatively large. Error for $1 \mathrm{~s} 2 \mathrm{~s}$ singlet-triplet energy splitting $\left(\mathrm{E}_{3}-\mathrm{E}_{2}\right)$ from the calculation in this study is higher than the calculation taken from the standard textbook perturbation theory calculation (474.95\% compared to $201.44 \%$ ). This is because in this calculation we only use 3 basis states, which are combinations of $1 \mathrm{~s}$ and $2 \mathrm{~s}$ orbitals (equation 19) and omit contributions from higher states $(3 \mathrm{~s}, 4 \mathrm{~s}, \ldots$, etc). Because $1 \mathrm{~s} 2 \mathrm{~s}$ excited states are higher in energy than the $1 \mathrm{~s}^{2}$ ground state, the formers' wave function (to first order) should depend more heavily on higher states than the latter's. Therefore, with only 3 basis states, we expect to have more errors in excited state energies than in ground state energy. The errors, however, are significantly reduced as the number of basis states in the wave function is increased by including higher states in this numeric calculation.

\section{Numeric Solutions to Energy Eigenvalue Equation using n Basis States $(3 \leq n \leq 25)$}

For $n>3$, analytic solutions would be very inefficient and difficult to obtain. Fortunately, this can be solved much faster and easier with the help of modern scientific software.

Masse and Walker [31] wrote a MATHEMATICA code to solve energy eigenvalue equation for the $\mathrm{He}$ atom using 7 basis states. Here, the code to calculate the $\mathrm{He}$ energies was modified using various basis states, ranging from 3 to 25 . By doing this, the convergence of current solutions can be investigated as a function of number of basis states as well as reduce the errors resulting from our previous analytic calculations.

The three lowest energy eigenvalues from the diagonalization of the Hamiltonian matrix correspond to $1 \mathrm{~s}^{2}$ (ground state), $1 \mathrm{~s} 2 \mathrm{~s}$ ${ }^{3} \mathrm{~S}_{1}$ (triplet state), and $1 \mathrm{~s} 2 \mathrm{~s}{ }^{1} \mathrm{~S}_{0}$ (singlet state), respectively. Results of the energy calculations with their errors are shown in Table 1. Experimental values of energy of $1 \mathrm{~s}^{2}$, $1 \mathrm{~s} 2 \mathrm{~s}$ triplet, and $1 \mathrm{~s} 2 \mathrm{~s}$ singlet states can be found in [32], where the energies being -2.90339 a.u., -2.17503 a.u., and -2.14577 a.u. for the respective states. 
Jurnal Penelitian Fisika dan Aplikasinya (JPFA), 2019; 9(1): 10-21

Table 1. Energies of the Three Lowest States of the He Atom (in atomic unit) for Different Number of Basis States and Their \% Errors

\begin{tabular}{|c|c|c|c|}
\hline $\mathrm{n}$ & $1 \mathrm{~s}^{2}(\%$ error $)$ & $1 \mathrm{~s} 2 \mathrm{~s}$ triplet (\% error) & 1s2s singlet (\% error) \\
\hline 3 & $-2.83044(2.51 \%)$ & $-2.12414(2.34 \%)$ & $-1.95591(8.85 \%)$ \\
\hline 4 & $-2.83458(2.37 \%)$ & $-2.16101(0.65 \%)$ & $-2.06923(3.57 \%)$ \\
\hline 5 & $-2.83865(2.23 \%)$ & $-2.16988(0.24 \%)$ & $-2.13619(0.45 \%)$ \\
\hline 6 & $-2.84002(2.18 \%)$ & $-2.17043(0.21 \%)$ & $-2.13639(0.44 \%)$ \\
\hline 7 & $-2.84138(2.14 \%)$ & $-2.17096(0.19 \%)$ & $-2.13660(0.43 \%)$ \\
\hline 8 & $-2.84202(2.11 \%)$ & $-2.17113(0.18 \%)$ & $-2.13677(0.42 \%)$ \\
\hline 9 & $-2.84265(2.09 \%)$ & $-2.17138(0.17 \%)$ & $-2.13694(0.41 \%)$ \\
\hline 10 & $-2.84300(2.08 \%)$ & $-2.17148(0.16 \%)$ & $-2.13704(0.41 \%)$ \\
\hline 11 & $-2.84335(2.07 \%)$ & $-2.17158(0.16 \%)$ & $-2.13714(0.40 \%)$ \\
\hline 12 & $-2.84356(2.06 \%)$ & $-2.17164(0.16 \%)$ & $-2.13721(0.40 \%)$ \\
\hline 13 & $-2.84378(2.05 \%)$ & $-2.17170(0.15 \%)$ & $-2.13727(0.40 \%)$ \\
\hline 14 & $-2.84392(2.05 \%)$ & $-2.17174(0.15 \%)$ & $-2.13731(0.39 \%)$ \\
\hline 15 & $-2.84406(2.04 \%)$ & $-2.17178(0.15 \%)$ & $-2.13735(0.39 \%)$ \\
\hline 16 & $-2.84416(2.04 \%)$ & $-2.17181(0.15 \%)$ & $-2.13738(0.39 \%)$ \\
\hline 17 & $-2.84425(2.04 \%)$ & $-2.17183(0.15 \%)$ & $-2.13741(0.39 \%)$ \\
\hline 18 & $-2.84432(2.03 \%)$ & $-2.17185(0.15 \%)$ & $-2.13743(0.39 \%)$ \\
\hline 19 & $-2.84439(2.03 \%)$ & $-2.17187(0.15 \%)$ & $-2.13745(0.39 \%)$ \\
\hline 20 & $-2.84444(2.03 \%)$ & $-2.17188(0.14 \%)$ & $-2.13747(0.39 \%)$ \\
\hline 21 & $-2.84450(2.03 \%)$ & $-2.17189(0.14 \%)$ & $-2.13748(0.39 \%)$ \\
\hline 22 & $-2.84454(2.03 \%)$ & $-2.17190(0.14 \%)$ & $-2.13750(0.39 \%)$ \\
\hline 23 & $-2.84458(2.03 \%)$ & $-2.17191(0.14 \%)$ & $-2.13751(0.38 \%)$ \\
\hline 24 & $-2.84461(2.02 \%)$ & $-2.17192(0.14 \%)$ & $-2.13752(0.38 \%)$ \\
\hline 25 & $-2.84464(2.02 \%)$ & $-2.17193(0.14 \%)$ & $-2.13753(0.38 \%)$ \\
\hline
\end{tabular}

From Table 1, it is clear that for $n>7$, the convergence is slow, with the maximum error reduction is $0.03 \%$ for $1 \mathrm{~s}^{2}$ state, $0.01 \%$ for $1 \mathrm{~s} 2 \mathrm{~s}$ triplet, and $1 \mathrm{~s} 2 \mathrm{~s}$ singlet states for each increase in the number of states. Despite being slow, the errors [31] for 7 basis states decrease as the number of states increases. As a comparison, for $n=25$, errors for the respective states are $2.02 \%, 0.14 \%$, and $0.38 \%$, compared to $2.14 \%, 0.19 \%$, and $0.43 \%$ [31]. This shows an error reduction of $0.12 \%$ for energy of $1 \mathrm{~s}^{2}$ state, of $0.05 \%$ for energies of $1 \mathrm{~s} 2 \mathrm{~s}$ triplet, and $1 \mathrm{~s} 2 \mathrm{~s}$ singlet states.

\section{Convergence of the Numeric Solutions}

To see the convergence of our solutions more clearly, the percentage errors in energies for all states are plotted versus number of states $(n)$, as shown in Figure 1.

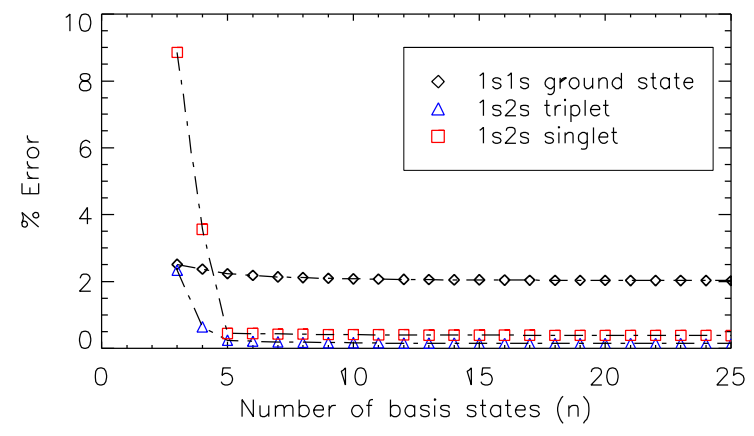

Figure 1. Errors in Energies are Plotted Against Number of Basis States

From Figure 1, it is obvious that errors in energies of all the 3 states are the highest for the smallest number of basis states $(n=3)$ and they are reduced as the number of states increases. This means that as the number of 
basis states increases, the theoretical energies get closer to the corresponding experimental values. This is expected as the more the number of basis states in the wave function, the more physical information contained and therefore, the wave function should represent more completely the quantum states of the system of interest. Thus, the results closest to the experimental values in this article are obtained for the largest number of basis states, i.e. $n=25$.

In addition, errors for energies of all three states are reduced rapidly between $n=3$ to $n=5$, with errors for $1 \mathrm{~s} 2 \mathrm{~s}$ singlet state experiencing the most dramatic reduction and the $1 \mathrm{~s}^{2}$ ground state having the least significant one. For $n \geq 5$, the errors for all the three states tend to be steady, indicating that adding more basis states would not significantly reduce the errors. This is due to the fact that higher $l$ orbitals and continuum are neglected in our basis states [31].

\section{Comparisons with Experimental Data and other Theoretical Energies}

Energy comparisons of the three lowest states of the He atom from our calculations and from other theoretical calculations as well as with the experimental data are shown in Table 2. Here, we only compare our calculations to $1^{\text {st }}$ order perturbation theory calculations and some other methods that use simple undergraduate quantum mechanics approaches.

Table 2. Comparisons of Energies from Our Calculations for $\boldsymbol{n}=25$ with Experimental Data and other Theoretical Calculations, with All Energies in Atomic Unit

\begin{tabular}{ccccc}
\hline States & $\begin{array}{c}\text { Experimental } \\
\text { data [32] }\end{array}$ & $\begin{array}{c}\text { This study } \\
(\% \text { error })\end{array}$ & $\begin{array}{c}\text { Matrix method with } 7 \\
\text { bases (\% error) [31] }\end{array}$ & $\begin{array}{c}1^{\text {st }} \text { order Perturbation } \\
\text { theory }(\% \text { error })[33]\end{array}$ \\
\hline $1 \mathrm{~s}^{2}$ & -2.90339 & $-2.84464(2.02 \%)$ & $-2.84138(2.14 \%)$ & $-2.74995(5.28 \%)$ \\
1s2s triplet & -2.17503 & $-2.17193(0.14 \%)$ & $-2.17097(0.19 \%)$ & - \\
1s2s singlet & -2.14577 & $-2.13753(0.38 \%)$ & $-2.13662(0.43 \%)$ & - \\
1s2s singlet-triplet & 0.02926 & $0.03440(17.57 \%)$ & $0.03435(17.39 \%)$ & $0.08820(201.44 \%)$ \\
splitting & & & & \\
\hline
\end{tabular}

It is clear from Table 2 that errors in this study are significantly lower than those from $1^{\text {st }}$ order perturbation theory. This applies to all energies of the three states. For $1 \mathrm{~s}^{2}$ state, with only 3 basis states, the calculations in this study have more accuracy than the standard perturbation theory calculations (2.51\% compared to $5.28 \%$ [33]). The error is significantly reduced to $2.02 \%$ by utilizing 25 basis states. This error of $2.02 \%$ is also smaller than that of $2.60 \%$ [10] and that of $2.14 \%$ [31], and comparable to others with errors of $1.44 \%[1-2,4]$. Of course, results from the simple calculation method in this study are not to be compared with highly accurate calculations using advanced methods such as the ones found in other studies
[5-7, 15, 17-18, 20-26] with errors being less than $0.20 \%$. For $1 \mathrm{~s} 2 \mathrm{~s}$ singlet-triplet energy splitting, the error from standard textbook perturbation theory is about $201.44 \%$. The error is significantly reduced to $17.57 \%$ in this research. Our 1s $2 \mathrm{~s}$ triplet and singlet state energies are also more accurate than Filippi et al [34], with errors being $0.14 \%$ and $0.38 \%$ from our calculations compared to about $0.23 \%$ and $0.52 \%$ [34], respectively.

All the results show that although the matrix approach applied here is very simple and straightforward, it can significantly reduce the errors obtained from standard $1^{\text {st }}$ order perturbation theory calculation found in undergraduate quantum mechanics textbooks. To further improve the accuracy 
Jurnal Penelitian Fisika dan Aplikasinya (JPFA), 2019; 9(1): 10-21

using this matrix approach, one would need to use more basis states in the wave function by including higher $l$-orbitals.

\section{IV.CONCLUSION}

It is shown that the simple matrix approach has been successfully applied to calculate three lowest energies of the Helium atom, i.e. $1 \mathrm{~s}^{2}, 1 \mathrm{~s} 2 \mathrm{~s}$ triplet, and $1 \mathrm{~s} 2 \mathrm{~s}$ singlet states. The time independent Schrodinger equation was analytically solved using three basis states and it was found that ground state $1 \mathrm{~s}^{2}$ energy of the He atom is much more accurate than that of the standard $1^{\text {st }}$ order perturbation theory. Although the analytic calculations in this study for energy splitting of 1s2s singlet-triplet still have relatively large errors, the errors are significantly reduced in the numeric calculations by adding the number of basis states in the wave function. In particular, when 25 basis states were used, the errors resulted from the calculations for $1 \mathrm{~s}^{2}$, $1 \mathrm{~s} 2 \mathrm{~s}$ triplet, and $1 \mathrm{~s} 2 \mathrm{~s}$ singlet states of the $\mathrm{He}$ atom were lower than those from the standard $1^{\text {st }}$ order perturbation theory. To conclude, it has been proven that the matrix approach can be used to obtain accurate energies on the three lowest states of the $\mathrm{He}$ atom using the common Quantum Mechanics skills for undergraduates. Therefore, this method can be applied in undergraduate classes in addition to the $1^{\text {st }}$ order perturbation theory to accurately calculate energies of quantum systems, especially the He atom.

\section{ACKNOWLEDGMENT}

We thank Professor Thad G. Walker and Dr. Robert C. Masse for the permission to use and modify their MATHEMATICA code.

\section{REFERENCES}

[1] Hall S and Siegel PB. Calculating Helium Atomic Excited States in Coordinate Space. American Journal of Physics. 2015; 83(12):
1028-1038. DOI:

https://doi.org/10.1119/1.4932549.

[2] Baseden KA and Tye JW. Introduction to Density Functional Theory: Calculations by Hand on the Helium Atom. Journal of Chemical Education. 2014; 91(12): 21162123. DOI:

https://pubs.acs.org/doi/abs/10.1021/ed5004 $\underline{788}$.

[3] Page TR, Boots CA, and Freitag MA. Quantum Chemistry: Restricted HartreeFock SCF Calculations Using Microsoft Excel. Journal of Chemical Education. 2008; 85(1): 159. DOI:

https://pubs.acs.org/doi/abs/10.1021/ed085p $\underline{159}$.

[4] Young TD, Vargas R, and Garza J. A Hartree-Fock Study of the Confined Helium Atom: Local and Global Basis Set Approaches. Physics Letter A. 2016; 380(56): 712-717. DOI:

https://doi.org/10.1016/j.physleta.2015.11.0 $\underline{21}$.

[5] Banerjee A, Kamal C, and Chowdhury A. Calculation of Ground- and Excited-state Energies of Confined Helium Atom. Physics Letter A. 2006; 350(1-2): 121-125. DOI: https://doi.org/10.1016/j.physleta.2005.10.0 $\underline{24}$.

[6] Aznabayev DT, Bekbaev AK, Ishmukhamedov IS, and Korobov VI. Energy Levels of a Helium Atom. Physics of Particles and Nuclei Letters. 2015; 12(5): 689-694. DOI:

https://doi.org/10.1134/S154747711505004 0 .

[7] Duan YS, Liu YX, and Zhang LJ. Corrections to the Nonrelativistic Ground Energy of a Helium Atom. Chinese Physics Letters. 2004; 24(9): 1714-1716. DOI: http://doi.org/10.1088/0256-307X/21/9/010.

[8] Al-Jaber SM. Variational Method for Ground-state Energy of Helium Atom in N Dimensions. Il Nuovo Cimento. 2010; 125B(9): 1099-1108. DOI: 
Jurnal Penelitian Fisika dan Aplikasinya (JPFA), 2019; 9(1): 10-21

http://dx.doi.org/10.1393/ncb/i2010-10907-

2.

[9] Flores-Riveros A, Aquino N, and Montgomery Jr. HE. Spherically Compressed Helium Atom Described by Perturbative and Variational Methods. Physics Letters A. 2010; 374(10): 12461252. DOI:

https://doi.org/10.1016/j.physleta.2009.12.0 62.

[10] Harbola V. Using Uncertainty Principle to Find the Ground-state Energy of the Helium and a Helium-like Hookean Atom. European Journal of Physics. 2011; 32(6): 1607-1615. DOI:

https://doi.org/10.1088/01430807/32/6/014.

[11] Baye D and Dohet-Eraly J. Confined Helium on Lagrange Meshes. Physical Chemistry Chemical Physics. 2015; 17(47): 3141731426. DOI:

http://dx.doi.org/10.1039/C5CP00110B.

[12] Nascimento DL, Fonesca ALA, and Portilho O. Determination of the Helium Atom Ground State through the Hamilton-Jacobi Equation. International Journal of Quantum Chemistry. 2005; 103(5): 505-508. DOI: https://doi.org/10.1002/qua.20591.

[13] Tsubono Y. Calculation of Helium Ground State Energy by Bohr's Theory-based Methods; 2009. Available from: https://arxiv.org/abs/0903.2546.

[14] Deeney FA and O'Leary JP. The Effects of the Pauli Exclusion Principle in Determining the Ionization Energies of the Helium Atom and Helium-like Ions. European Journal of Physics. 2012; 33(3): 667-675. DOI: https://doi.org/10.1088/0143-0807/33/3/667.

[15] Liverts EZ and Barnea N. Analytic Matrix Elements for the Two-electron Atomic Basis with Logarithmic Terms. Journal of Mathematical Physics. 2014; 55(8): 082104:1-12. DOI: https://doi.org/10.1063/1.4890562.
[16] Wiese WL and Fuhr JR. Accurate Atomic Transition Probabilities for Hydrogen, Helium and Lithium. Journal of Physical and Chemical Reference Data. 2009; 38(3): 565719. DOI:

https://doi.org/10.1063/1.3077727.

[17] Ekong SA, Oloye MT, and Oyegoke DA. Ground-state Energy Calculation of Helium Atom using Quantum Monte Carlo CASINO-Code. Advances in Physics Theories and Applications. 2015; 46: 1-7. Available from:

https://pdfs.semanticscholar.org/a8cb/14b8b 28759071e700f332a365b650d53cb2c.pdf.

[18] Doma SB and El-Gammal FN. Application of Variational Monte Carlo method to the Confined Helium Atom. Journal of Theoretical and Applied Physics. 2012; 6(28): 1-7. DOI: https://doi.org/10.1186/2251-7235-6-28.

[19] Suleiman $A B$ and Usman A. Ionization Energy of Screened Helium by Variational Quantum Monte Carlo Method. International Journal of Science and Nature. 2013; 4(2): 311-315. Available from: http://scienceandnature.org/IJSN_Vol4(2)J2 013/IJSN-VOL4(2)13-14.pdf.

[20] Doma SB and El-Gammal FN. Monte Carlo Variational Method and the Ground-state of Helium. Systemics, Cybernetics and Informatics. 2009; 7(5): 78-83. Available from:

$\underline{\text { http://www.iiisci.org/journal/CV\$/sci/pdfs/ }}$ XS180FR.pdf.

[21] Suleiman AB and Ewa IOB. Path Integral Monte Carlo Formulations and the Ground State Energy of Helium Atom. International Journal of Science and Nature. 2012; 3(4): 815-818. Available from:

http://scienceandnature.org/IJSN_Vol3(4)S2 012/IJSN-VOL3(4)12-15.pdf.

[22] Zheng $\mathrm{W}$ and Ying L. Finite-element Calculations for the Helium Atom. International Journal of Quantum 
Jurnal Penelitian Fisika dan Aplikasinya (JPFA), 2019; 9(1): 10-21

Chemistry. 2003; 97(1): 659-669. DOI:

https://doi.org/10.1002/qua.10770.

[23] Sasmal GP. A Finite Volume Approach for Solving the Ground State Helium. Journal of Physics B: Atomic, Molecular and Optical Physics. 2009; 42(22): 1-11. DOI: http://dx.doi.org/10.1088/09534075/42/22/225001.

[24] Nakashima H, Hijikata Y, and Nakatsuji H. Solving the Electron and Electron-nuclear Schrödinger Equations for the Excited States of Helium Atom with the Free iterativecomplement-interaction Method. The Journal of Chemical Physics. 2008; 128(15): 154108. DOI: https://doi.org/10.1063/1.2904871.

[25] Ruiz MB. Hylleraas-configuration Interaction Calculations on the $1^{1} \mathrm{~S}$ Ground State of Helium Atom. Journal of Coordination Chemistry. 2015; 68(17-18): 3340-3361. DOI:

https://doi.org/10.1080/00958972.2015.106 4907.

[26] Montgomery Jr. HE, Aquino N, and FloresRiveros A. The Ground State Energy of a Helium Atom under Strong Confinement. Physics Letters A. 2010; 374(19-20): 20442047. DOI:

https://doi.org/10.1016/j.physleta.2010.02.0 74.

[27] Laughlin C and Chu SI. A Highly Accurate Study of a Helium Atom under Pressure. Journal of Physics A: Mathematical and Theoretical. 2009; 42(26): 265004. DOI: https://doi.org/10.1088/1751$8113 / 42 / 26 / 265004$.
[28] Hutchinson J, Baker M, and Marsiglio F. The Spectral Decomposition of the Helium Atom Two-electron Configuration in terms of Hydrogenic Orbitals. European Journal of Physics. 2013; 34(1): 111-128. DOI: https://www.doi.org/10.1088/01430807/34/1/111.

[29] Acosta CR, Tapia JA, and Cab C. Restricted Closed Shell Hartree Fock Roothaan Matrix Method Applied to Helium Atom using Mathematica. European Journal of Physics Education. 2014; 5(1): 1-14. DOI: https://doi.org/10.20308/ejpe.v5i1.58.

[30] Liverts EZ and Barnea N. S-states of Heliumlike Ions. Computer Physics Communications. 2012; 183(3): 844-845. DOI:

https://doi.org/10.1016/j.cpc.2011.11.001.

[31] Masse RC and Walker TG. Accurate Energies of the He Atom with Undergraduate Quantum Mechanics. American Journal of Physics. 2015; 83(8): 730-732. DOI: https://doi.org/10.1119/1.4921821.

[32] Sansonetti JE and Martin WC. Handbook of Basic Atomic Spectroscopic Data. Journal of Physical and Chemical Reference Data. 2005; 34(4): 1559-2259. DOI:

https://doi.org/10.1063/1.1800011.

[33] Bransden BH and Joachain CJ. Quantum Mechanics. 2nd Edition. New Jersey: Prentice Hall; 2000.

[34] Filippi C, Umrigar CJ, and Gonze $\mathrm{X}$. Excitation Energies from Density Functional Perturbation Theory. The Journal of Chemical Physics. 1997; 107(23): 999410002. DOI: http://dx.doi.org/10.1063/1.475304. 